\title{
Religion Education in Norway: Tension or Harmony between Human Rights and Christian Cultural Heritage?
}

\author{
BENGT-OVE ANDREASSEN \\ University of Tromsø
}

\begin{abstract}
Both research and public and scholarly debate on religious education (RE) in Norway have mostly revolved around the subject in primary and secondary school called Christianity, Religion and Ethics (KRL) (later renamed Religion, Philosophies of Life and Ethics, RLE), not least due to the criticisms raised by the UN's Human Rights Committee in 2004 and the European Court of Human Rights (ECHR) in 2007 of the Norwegian model for RE in primary and secondary schools. The RE subject in upper secondary school, however, is hardly ever mentioned. The same applies to teacher education. This article therefore aims at providing some insight into how RE has developed in the Norwegian educational system overall, ranging from primary and secondary to upper secondary and including the different forms of teacher education.
\end{abstract}

Keywords: religious education, teacher education, educational system, human rights, Norway

\section{Historical Background}

The development of religious education (RE) in Norway can be described in three main perspectives which link with historical periods: firstly, the Christian education policy in the period from 1736 (when confirmation was made obligatory for all people) to 1860; secondly, the gradual secularisation of the school from 1860, as new subjects supplemented and challenged Christianity as the main curricular focus in schools, to 1969, when a new Education Act stated that RE should no longer should be confessionally rooted in Christianity. The period of religious instruction in Norwegian schools was then formally over, and 'separative religious education', in what has been 
labelled the 'parallel model', was introduced. ${ }^{1}$ The third period, from 1969 up until the present, with increased globalisation and the development of Norwegian society towards increased multiculturalism, has been characterized by the emergence of new ideas for thinking about RE in the now more secular as well as multi-cultural school. Through the 1990s, and into the new millennium, the Norwegian state's commitments to international conventions concerning human rights also became of major importance.

The extensive tradition of Christianity in Norway long made RE in school and also in teacher education a subject firmly in the theologians' hands (Skeie 2003, 192-3). This significantly influenced thinking and basic perspectives on RE (cf. Andreassen 2009), even though educational debate in the 1990s was directed towards the society's growing cultural and religious diversity. Arguments relating to the increasingly multicultural and secular society were constantly present in the debate, urging the state to rethink RE and reduce the state church's presence in the public state school. Although the 1969 Education Act for primary and secondary schools had separated 'Knowledge of Christianity' (Kristendomskunnskap) from baptismal instruction in the Church, in practice a close relationship with the Church continued (cf. Skeie 2003). The presence of the Church in schools, taken for granted through previous centuries in Norwegian school history, was now, in the 1990s, questioned as a potential violation of the rights of minorities with other religious backgrounds. This re-launched the idea of a new integrative RE subject for all pupils in school, regardless of their background, religious or not.

The debate regarding RE in primary and secondary school in the 1990s thus, in the main, focused on whether or not the separative model should continue, and whether it was possible to have a compulsory integrative RE subject (cf. Wingård 2003). An official group of experts was appointed by the Ministry to make recommendations concerning these issues, and in 1995 published an official report entitled Identity and dialogue (NOU 1995:9). The group recommended the establishment of a compulsory, integrative 'extended Knowledge of Christianity subject' (et utvidet kristendomsfag). The subject should include world religions, philosophy and ethics, yet the central focus should still be on Christianity. Christianity and ethics should thus also constitute the core contents in the first to fourth grades. From the fifth grade, teaching should include other religions and secular worldviews.

1 The description 'separative religious education' (as opposed to integrative religious education), as introduced by Wanda Alberts (2007), fits the Norwegian 'parallel model' until 1997: a model in which pupils (or their parents) could choose between Christianity or Ethics education. 
In the report, holding on to Christianity as the core contents was justified with reference to the importance of Christianity as 'cultural heritage' as well as the largest world religion. The reasoning, furthermore, drew heavily on the general Core Curriculum for primary, secondary, upper secondary and adult education, implemented the year before. Here, Christianity was - and still is - described as 'a deep current in our history - a heritage that unites us as a people across religious persuasions' (Core Curriculum 1993, 7). ${ }^{2}$

When the official report and a new RE subject were debated in the Norwegian parliament (Stortinget) in October 1995, the 'cultural heritage' perspective seemed self-evident. ${ }^{3}$ There was also agreement on the general profile, with reference to the report's title 'Identity and Dialogue', that the subject should focus on developing and supporting children's identity in the primary and secondary phases, and be more oriented on dialogue in the secondary and upper secondary. Nevertheless, many MPs argued for a wider perspective than the original proposal of ' an extended Knowledge of Christianity subject', and it was this perspective that prevailed: all religions, secular world views, philosophy and ethics should be introduced from the first grade (Innst. S. nr. 103, 1995-1996).

\section{Introducing an Integrative Compulsory RE in Primary and Secondary Schools - Critique and Revisions}

In 1997, the new subject, KRL (Christianity, Religion and Ethics) was introduced as compulsory and integrative in primary and secondary schools, replacing the parallel model and the subjects 'Knowledge of Christianity' and 'Ethics education', but with limited possibility for exemption. The Norwegian Humanist Association and religious minorities strongly opposed KRL and argued that it failed to meet the requirements of a genuinely neutral and thus 'common' subject. From their viewpoint, it still bore the imprint

2 The core curriculum as it was implemented in 1993 still applies for primary, secondary, upper secondary and adult education. However, in a White Paper (report to the Parliament) published in March 2013, the Ministry of Education signals that a new core curriculum will be developed. The White Paper states that the Ministry finds a need to develop a new core curriculum which better reflects Norwegian society (St. meld. Nr. 20 2012-2013, 60). The English version of the current version is available here: http://www.udir.no/Upload/larerplaner/ generell_del/5/Core_Curriculum_English.pdf?epslanguage=no [last visited 10 July 2013].

3 Wingård (2003) analyses different perspectives in the debate concerning RE in the 1990s. 
of the Christian statement of intent ${ }^{4}$ in the first section of the Education Act (Rasmussen 2000, 19; Haakedal 2001, 93ff; Skeie 2006, 24).

The first curriculum for the KRL subject in 1997 also had the imprint of the original idea of an extended Christianity subject. The main subject areas were:

Table 1: KRL 1997, in L97, page 92 (my translation).

\begin{tabular}{|l|l|l|l|}
\hline Main subject area & Primary stage 1-4 & Primary stage 5-7 & Secondary stage 8-10 \\
\hline $\begin{array}{l}\text { Knowledge of the } \\
\text { Bible }\end{array}$ & $\begin{array}{l}\text { Central stories from } \\
\text { the Bible }\end{array}$ & Stories of the Bible & $\begin{array}{l}\text { Different genres in } \\
\text { the Bible, the Bible as } \\
\text { a holy text, history of } \\
\text { the Bible }\end{array}$ \\
\hline $\begin{array}{l}\text { History of Chris- } \\
\text { tianity }\end{array}$ & $\begin{array}{l}\text { Stories from the his- } \\
\text { tory of Christianity }\end{array}$ & $\begin{array}{l}\text { Early history of } \\
\text { Christianity: de- } \\
\text { velopment, people, } \\
\text { cultural expressions }\end{array}$ & $\begin{array}{l}\text { Modern history of } \\
\text { Christianity: develop- } \\
\text { ment, people, cultural } \\
\text { expressions }\end{array}$ \\
\hline $\begin{array}{l}\text { Christian life in- } \\
\text { terpretation today }\end{array}$ & $\begin{array}{l}\text { Christian holidays, } \\
\text { religious symbols, } \\
\text { Christianity in local } \\
\text { communities }\end{array}$ & $\begin{array}{l}\text { Christian faith and } \\
\text { ethics }\end{array}$ & $\begin{array}{l}\text { Christian churches, } \\
\text { similarities and dif- } \\
\text { ferences }\end{array}$ \\
\hline Other religions & $\begin{array}{l}\text { Other religions } \\
\text { and views of life } \\
\text { (livssyn), stories and } \\
\text { festivals }\end{array}$ & $\begin{array}{l}\text { Islam, Judaism, Hin- } \\
\text { duism, Buddhism, } \\
\text { secular views of life } \\
\text { (verdslige livssyn })\end{array}$ & $\begin{array}{l}\text { Religion in our time } \\
\text { / contemporary } \\
\text { religion }\end{array}$ \\
\hline Ethics/Philosophy & $\begin{array}{l}\text { Ethical awareness: } \\
\text { mine and yours, me } \\
\text { and others }\end{array}$ & $\begin{array}{l}\text { Ethical awareness: } \\
\text { values and choices }\end{array}$ & $\begin{array}{l}\text { Philosophical } \\
\text { interpretations of } \\
\text { humankind: values } \\
\text { and norms }\end{array}$ \\
\hline
\end{tabular}

The first years of the implementation of the KRL subject were evaluated by two groups of researchers. Their assessments were published in two reports (Aadnanes \& Johannessen 2000; Hagesæther et al. 2000). Not surprisingly, one of the main conclusions was that the subject was overloaded. There was simply too much to teach. In addition, teachers were uncertain how much time they were supposed to spend on the different areas of the curriculum.

4 The Christian statement of intent refers to the special reference to Christianity in the first section of the Education Act for primary and secondary education. In $\S 1$ Principal Aims it read: 'Primary and lower secondary education shall, with the understanding of and in cooperation with the home, assist in providing pupils with a Christian and ethical upbringing [...]' (cited after the official English translation printed in the Core Curriculum (1993) See footnote 2 for the link to the English version). This formulation has later been removed and the paragraph adjusted. 
Therefore, work on a first revision began in 2001 and a new curriculum with a reduced and revised content was introduced in 2002. The curriculum now stated that 55 per cent of the teaching should focus on Christianity, 25 per cent on other religions and views of life (livssyn) and 20 per cent on ethics and philosophy. A proposal from some of the experts to get rid of the bias inherent in the 'Christianity + others' structure by replacing it with a more thematic type of organisation, was not followed by the Ministry. The old hierarchical model, with Christianity on top, was retained (Thomassen 2006, 259-60).

From the very beginning of the work towards a revised RE, the question regarding the right to (limited or full) exemption attracted much attention. The Ministry of Church, Education and Research was aware of this and engaged Judge Erik Møse to conduct an investigation into the legal issues involved, and especially whether the new subject, seen in relation to the Christian statement of intent in the Education Act, was in conflict with the Norwegian state's obligations to international conventions concerning human rights. Møse (1998) concluded that the subject did not fail to meet human rights obligations, but recommended a general right to exemption. However, after debates in the Parliament during spring 1997, only a limited right to exemption was retained and applied when the KRL was put into practice in fall. In the Education Act for primary and secondary it read, $\S 13$ (section 9):

KRL is a school subject supposed normally to include all pupils.

By written notification from parents/guardians, pupils shall be exempted from those parts of the teaching at the specific school that they [pupils and parents], on the basis of their own religion or view of life (livssyn) experience as practice of another religion or as adherence to another view of life (livssyn). This may, for example, include religious activities in or outside the classroom. In case of notification of exemption, the school should, as far as possible and especially in the lower stages (1-4 grade), try to find solutions by facilitating differentiated teaching in accordance with the curriculum. (Innst. O. nr. 95, 1996-1997, 32-3; my translation.)

However, there was more to it: the Norwegian Islamic Council and The Norwegian Humanist Association, in conjunction with independent parents, brought a lawsuit against the Norwegian state, claiming the right to full exemption from KRL. Their case went through the entire Norwegian legal system, and in August 2001 the Supreme Court finally also ruled against the applicants, deciding that both Norwegian law and curricula were in 
accordance with Norway's obligations to human rights. At the same time, the court raised the question of whether the law was being practised in accordance with these obligations, and by doing so, indirectly invited the applicants to file another lawsuit in the future (Høstmælingen 2004, 300). Accordingly, one group of parents (Folgerø et al. vs. Norway), supported by the Humanist Association, filed a petition to the European Court of $\mathrm{Hu}-$ man Rights (ECHR) in Strasbourg, while another group (Leirvåg et al. vs. Norway) filed a petition to the UN's Human Rights Committee in Geneva. From this point on, Norwegian RE, i.e. KRL, 'entered' a Human Rights legal discourse on religious freedom and human rights (cf. Plesner 2013).

In November 2004, a communiqué from the UN's Human Rights Committee was published. ${ }^{5}$ The Committee's communiqué was in favour of the applicants and, inter alia, remarked:

[T]he existing normative framework related to the teaching of the CKREE [abbreviation for KRL used by UN] subject contains internal tensions or even contradictions. On the one hand, the Constitution and the object clause in the Education Act contain a clear preference for Christianity as compared to the role of other religions and worldviews in the educational system. (UN Human Rights Committee 2004, Article 14.5.)

It further commented on the system of partial exemption. In the Committee's view, this practice

[...] imposes a considerable burden on persons in the position of the authors [i.e. parents], insofar as it requires them to acquaint themselves with those aspects of the subject which are clearly of a religious nature, as well as with other aspects with a view to determining which of the other aspects they may feel a need to seek - and justify - exemption from (UN Human Rights Committee 2004, Article 14.6).

The UN Human Rights Committee concluded that Norway was in violation of Article 18 of the Human Rights Code.

In 1999, the Norwegian state had incorporated the European Human

5 The Norwegian state had to publish the UN committee's statement: 'The State party is also requested to publish the Committee's statement/opinion' and did so on the government's official website: http://www.regjeringen.no/nb/dokumentarkiv/Regjeringen-Bondevik-II/ ufd/233191/251920/Human-Rights-Committee-Communication-No-11552003.html?id=422478\# [last visited 2 July 2013]. 
Rights Convention as well as the two major UN Human Rights conventions into national law, in the Menneskerettsloven ('Human Rights Act'). Furthermore, Norway saw itself as a promoter of human rights in general. The criticism, consequently, was rather embarrassing for the Norwegian state, and the Norwegian government therefore wanted to take effective and appropriate measures in response to the UN's criticism.

However, there was yet another reason: the Prime Minister, Kjell Magne Bondevik, ${ }^{6}$ representing the Norwegian Christian Democratic Party, had promoted the Norwegian model for RE as an important tool in the war against terror and for resolving international conflicts. However, in November 2004, instead of presenting KRL as a means in the war against terror, Bondevik had to deal with the UN criticism seeing KRL as a violation of human rights.

As a result of the Human Rights Committee's criticism, the curriculum for KRL and rules for exemption were revised and put into practice in June 2005. However, children could still be exempted only from certain parts of the teaching, and thus a right to full exemption was not introduced. The relevant text read:

On the basis of written notification from parents, pupils shall be exempted from attending those parts of the teaching at the individual school that they, on the basis of their own religion or philosophy of life (livssyn $)^{7}$, perceive as being the practice of another religion or adherence to another philosophy of life (livssyn), or which they for the same reasons find offensive or objectionable. It is not necessary to provide reasons for a notification of exemption pursuant to the first sentence.

It is not possible to demand exemption from the knowledge content in the various syllabus topics. If a school on such grounds does not accept a notification of exemption, the school must handle the case pursuant to the rules

6 Bondevik was Prime Minister in two periods: from 1997-2000 and from 2001-2005. At official state visits in Israel and Iran, and when the Moroccan Prime Minister visited Norway in 2004, Bondevik had argued that a school subject such as the Norwegian KRL could have such functions. Norwegian newspapers published Bondevik's presentation of KRL in the international scene: http://www.nrk.no/nyheter/innenriks/4145373.html [last visited 2 July 2013], and http:// www.aftenposten.no/amagasinet/article1154208.ece [last visited 2 July 2013]. The links are to articles in Norwegian only. In his speech opening the conference The Religious Dimension of Intercultural Education in Oslo in June 2004, some of Bondevik's perspectives on how religions (and knowledge about religion) can be a way of resolving conflict can be found, although in this speech he does not mention the KRL subject explicitly (Bondevik 2006).

7 Cf. footnote 5. 
relating to individual decisions in the Norwegian Public Administration Act. When the school receives a notification of exemption, it must ensure that the pupil in question is excused in actual practice, and facilitate for individually adapted and differentiated teaching within the scope of the syllabus. (Udir. 2005, 70; official translation.)

Almost two years after the Human Rights Committee's statement, in June 2007, the ruling from the ECHR was published in the case entitled Folgerø et al. vs. Norway (application no. 15472/02). ${ }^{8}$ Although this was the contested ruling of a 9-8 majority among the judges, ${ }^{9}$ once again, the Norwegian state was the object of harsh criticism. The ruling stated that parents' freedom to ensure that their children's education was in conformity with their own religious and philosophical convictions was violated by KRL. Once again, revision of the KRL had to be undertaken. In a circular (F-10-08) ${ }^{10}$, issued in June 2008, The Ministry of Education and Research announced that the name had been changed from KRL to RLE (in English: Religion, Philosophies of life and Ethics).

In the circular, the Ministry commented on the changes that had to be made in accordance with the ruling of the ECHR (Circular F-10-08; my translations):

The changes are a necessary follow-up to bring the subject in accordance with human rights after the ruling of the European Court of Human Rights (ECHR) that frames the subject in law and states that the curriculum violated the European Convention on Human Rights. The Convention is superior to Norwegian law.

[...]

The ECHR finds that there are qualitative differences in the teaching of Christianity in relation to the other parts of the subject, and therefore believes that it is unclear how the profession's purpose to promote understanding, respect and dialogue, can be reached. Against this background, the court concludes that the Christian elements in the subject are in violation of the European Convention on Human Rights. Several of the formulations that are criticised

8 The complete ruling is found on ECHR's website: http://hudoc.echr.coe.int/sites/eng/pages/ search.aspx\#\{“dmdocnumber":["819532”],"itemid”:[“001-81356"]\} [last visited 2 July 2013].

9 The Norwegian scholar Sidsel Lied (2009) discusses the ruling, emphasizing the dissent among the judges and using this dissent to question the relevance of the verdict.

10 The circular F-10-08 is available on the government's website (in Norwegian only): http:// www.regjeringen.no/nb/dep/kd/dok/rundskriv/2008/rundskriv-f-10-08-informasjon-omendring.html?id=520814 [last visited 2 July 2013]. 
in the verdict in the earlier legal framework, have not been changed since 1997. [...]

The name of the subject is changed to Religion, Philosophies of Life (Livssyn) and Ethics. The name change will clarify that the religions and beliefs should be treated in a qualitatively equal way. [...] Knowledge of Christianity shall have the largest share of the content of the teaching without qualitative differences compared to other subject areas. This is due to Christianity's influence in Norway through history and as cultural heritage.

$[\ldots]$

At the same time, teaching about Christianity must not have so much room that it leads to qualitative differences, for which the ECHR in its ruling criticises the curriculum of 1997.

A new revised curriculum, ${ }^{11}$ which also is the current curriculum for RE in primary and secondary schools, with the new name RLE, was introduced just before the start of the school year 2008/2009. According to the circulars issued by the Ministry, the subject is now in compliance with human rights conventions and provides a basis for a qualitatively equal treatment of the different religions. Nonetheless, a critical eye can still detect some internal tensions in the curriculum. The introduction, stating the objectives of the subject, reads:

The subject shall teach knowledge of Christianity, other world religions and philosophies of life (livssyn), and ethical and philosophical themes. It shall also teach the significance of Christianity as cultural heritage in our society. For this reason, Knowledge of Christianity will be a major portion of the learning content of the subject. (RLE08, 1; official translation, italics in original document. See footnote 11 for a link to the complete document.)

Thus, knowledge about Christianity is still intended to make up the major part of the learning content, both as cultural heritage and as one of the main subject areas. Even though the Ministry considers the subject now to be in compliance with human rights, it can nevertheless still be questioned whether Christianity is not treated in a qualitatively different way compared to other religions. However, in the new curriculum, a completely new paragraph was included as a direct reply to the ECHR's ruling:

11 Cf. link to the RLE curriculum in English is found on this webpage: http://www.udir. no/Stottemeny/English/Curriculum-in-English/_english/Curricula-in-English/ [last visited 2 July 2013]. 
The Norwegian Education Act demands that the teaching of this subject be objective, critical and pluralistic. ${ }^{12}$ This implies that the subject be taught impartially and based on facts, and that the different world religions and philosophies of life (livssyn) shall be presented with respect. Classroom teaching shall not include preaching, proselytising or religious practice. The principles of equivalent education ${ }^{13}$ shall be the basis for teaching in the subject. This involves treating all religions and philosophies of life (livssyn) in an academic and professional manner based on the distinctive characteristics and diversity of all religions. (RLE08, 1.)

In addition, or as part of putting these principles into practice, the curriculum now also includes comments concerning ways of teaching - in the official translation formulated as 'working methods':

Teaching in the subject shall use varied and absorbing working methods, which can contribute to understanding in all aspects of the subject. Care must be used when selecting working methods. The careful choice of working methods is especially important when considering parents, guardians and pupils so that they feel their own religion or philosophy of life (livssyn) is respected and that the subject be experienced without seeming to exercise another religion or forming an affiliation to another philosophy of life (livssyn). (RLE08, 1.)

A clear tendency in the development for RE in primary and secondary schools has thus been towards ensuring that RE today cannot be understood or interpreted as practice of or affiliated to a specific religion.

\section{The Current Situation of RE in Primary and Secondary Schools from a Study-of-religions Perspective}

The formulations in the Education Act as well as in the curriculum for RLE prescribing 'objective, critical and pluralistic' teaching, 'impartial and based

12 The phrase 'objective, critical and pluralistic' is the standard formulation used by ECHR and also used by the US supreme court in rulings concerning teaching religion in public school. It was as a result of ECHR's ruling in the case Folgerø and Others vs. Norway that this phrase was included in the Education Act (§ 2-4) and the curriculum for RLE in 2008.

13 The phrase 'equivalent education' refers to ways of teaching and pedagogical principles in teaching. In other words, and in reference to the earlier curricula, it means that every religion should be taught in the same way. In the Norwegian version this sentence reads: 'Likeverdige pedagogiske prinsipper skal legges til grunn'. This phrase is used both in the curriculum and in the Education Act (§ 2-4). 
on facts', and the treatment of all religions 'in an academic and professional manner', make the academic Study of Religions seem more relevant than ever. No other academic discipline can provide and apply such principles in teaching about religion(s) in school (cf. Jensen 2008, 2011).

From the point of view of the academic Study of Religions, the development in RE in primary and secondary schools must be welcomed. Still, the fact that Christianity is still the main subject area and is characterized as 'our cultural heritage', with at least one third of the teaching in RE devoted to Christianity, does constitute a problem. There is a real risk that Christianity becomes the nodal point for teaching, and thus, the starting point for comparison and teaching about 'other' religions. One might also argue that there is a deliberately different approach to Christianity as compared to that of other religions. This is also reflected in a separate paragraph (\$ 2-4) for RE in the Education Act (Opplxringslov). It reads:

The teaching in religion, philosophies of life (livssyn) and ethics shall provide knowledge of Christianity, other world religions and philosophies of life (livssyn), knowledge of what Christianity has to say as cultural heritage and about ethical and philosophical topics (my translation).

Consequently, the Study of Religions scholar Wanda Alberts (2011, 110) has suggested that the current curriculum would be better reflected in the name KRLE (Christianity, Religions, Philosophies of Life (livssyn) and Ethics) rather than in RLE (Religions, Philosophies of Life (livssyn) and Ethics). On the other hand, one might argue, with reference for example to the fact of a thousand-year long history of Christianity in Norway, that this is a good reason for giving more space to Christianity than to any other individual religion. The important question is whether the Education Act and the curriculum, through the 'cultural heritage perspective', provide a qualitative and not only a quantitative difference between Christianity and other religions, which would again be in contravention of the human rights legislation.

On the 30th September 2013, after about five years of relative political peace and quiet concerning RLE in primary and secondary school, the four political parties proposing to form a new coalition presented their manifesto for the next four years. One of the specific points of the manifesto is that 
the name of the RLE subject will be changed to KRLE. ${ }^{14}$ The political parties, one of them being the Norwegian Christian Democratic Party, which made this question an issue in their election campaign, have also agreed that the curriculum should state that at least 55 per cent of the teaching should be about Christianity. The manifesto does not say anything about what percentages the other parts of the subject should have. Nevertheless, it is clear from this proposal that the main concern seems to be to secure an extended focus on Christianity. However, from the perspective of Study of Religions, this represents a real setback for the development of RE in Norway, as it re-introduces the old Christianity + others model, in which most of the teaching should revolve around Christianity.

\section{No Debate at all: RE in Upper Secondary Education}

The aforementioned official report, NOU 1995:9, also discussed religion as a school subject in upper-secondary school. ${ }^{15}$ While the public and scholarly debate about the new KRL subject in primary and secondary schools reached a peak in the late 1990s, the subject in upper secondary school was hardly mentioned at all. Part of the explanation probably has to do with the fact that an RE subject with a profile of general information and education had existed in upper secondary education since 1976.

In the period from 1935 to 1976, the subject in upper secondary school was named 'Knowledge about Christianity' (Kristendomskunnskap). In 1976, it was changed to 'Religion', and included 'world religions' and religion in Asia and Africa. In 1995, when the official report advocated a new and extended 'Knowledge about Christianity' subject for primary and secondary schools, the subject 'Religion' in upper secondary education had thus already had a general orientation profile for 20 years. In 1996, a new name and new curriculum for 'Religion and Ethics' (Religion og etikk) (RE96), did

14 In Norwegian: 'RLE-faget endrer navn til KRLE (Kristendom, religion, livssyn og etikk), og kravet om at faget, $\mathrm{i}$ tråd med kompetansemålene, skal inneholde minst 55 pst kristendom gjeninnføres'. Link to agreement: http://www.hoyre.no/filestore/Filer/Politikkdokumenter/ Samarbeidsavtale.pdf [visited 1 October 2013]. See page 4, point L.

15 I use the English term 'upper-secondary' for what in Norwegian is referred to as videregående skole or gymnas (gymnasium). This is a period of three years and pupils can choose between different programs. In the program for general Studies, the subject 'Religion and ethics' is obligatory. Teaching is about three hours a week. This is very similar to the situation in Denmark. 
not inspire any public debate at all. ${ }^{16}$ Neither the legal framework nor the references to the state's obligations to human rights was an issue of debate, and there were no public debates when new curricula for the subject were introduced in 1996 and 2006, even if the same framework that applied for primary and secondary school applied also for upper secondary. ${ }^{17}$

While the new KRL subject was to be primarily orientated towards the 'identity' of the pupils and the Norwegian state and culture, the subject in secondary and upper secondary schools should also focus on 'dialogue'. In upper secondary school, students should be ready to engage in dialogue, after having their (Christian) religious identity consolidated in primary and secondary education. The few scholars who commented on the new curriculum, presented in 1996, seemed to agree that central concepts like identity and dialogue led to a subject in upper secondary which had a more existential profile than previously (cf. Skottene 1997, Leirvik 2001).

The curriculum for RE in upper secondary also revolved around Christianity, much like the curriculum for RE in primary and secondary. In addition to being a separate main subject area, with about one third of the teaching, the term 'living non-Christian religions' (levende ikke-kristne religioner) ${ }^{18}$ that was applied to Judaism, Islam, Hinduism and Buddhism, also defined them by reference to Christianity. Among the different religions, Judaism and Islam were compulsory, and the teacher (and pupils) could then either choose Hinduism, Buddhism or a New Religious Movement.

The curriculum for 'Religion and Ethics' was the subject of harsh criticism from the Sami Institute (Sámi instituhtta). In an official report evaluating

16 Still, the draft of the curriculum for 'Religion and ethics' was the one which where most commented among school subjects when it was circulated in a hearing process at schools, universities, university colleges and different interest groups (cf. Østnor 1997, 4). But it was not discussed in public.

17 Until 1998 there were two separate laws (Education Acts). One for primary and secondary schools, and one for upper secondary school. In 1998, the parliament decided to have one common Education Act for the whole school system. This should ensure that all thirteen years in school were seen as an integrated totality. The 1993 Core Curriculum was meant to function as a regulation (forskrift) that complements the law. As the Core Curriculum has a legal status as a regulation (forskrift) it is regarded as equivalent to law. Even though the Education Act has been adjusted concerning the orientation on Christian values and human rights (last time in 2008), the core curriculum has not been adjusted or revised since 1993. This means that the Norwegian legal framework for school has been out of tune with itself. Or, at least, there is a tension between the different parts of the framework. However, the process of developing a new core curriculum was initiated by the ministry of Education in a report to parliament in spring 2013.

18 The main subject area for 'other religions' was labeled 'living [or contemporary] nonChristian religions'. 'Other religions' were thus referred to as 'non-Christian religions'. 
how curricula in upper secondary education included perspectives on Sami culture and language, it said that the curriculum for 'Religion and Ethics' (RE96) ' $[. .$.$] is written from a Christian, Lutheran perspective, and other$ religions and philosophies are interpreted from a Christian point of view. This makes the curriculum seem exclusive towards pupils with other religious backgrounds or convictions' (Sámi instituhtta 2000, 135). ${ }^{19}$ And further: 'The curriculum is written as if Norwegian religious history started with Christianity' (ibid.). The criticism from the Sámi instituhtta, highlighting the central place of Christianity in the curriculum, and the emphasis on faith and confession, and on the European and Norwegian Christian heritage, left no space for indigenous people. Even if this criticism was made from a Sámi and ethno-political vantage point, it was relevant because it raised the question of both a quantitative and a qualitative bias towards Christianity.

Apart from the special Christian profile, an interesting feature in the RE96 curriculum was another special emphasis on Islam. In the introduction of the curriculum it was stated that Islam was a religion of special importance in Norwegian society:

Dealing with non-Christian religions, it is natural that those religions which are strongly represented in Norwegian society are given particular emphasis. Islam is such an important religion, both internationally and in Norway that it has been allotted more space than other non-Christian religions in the subject (RE96, 3; my translation).

With more space to Islam, religions in Africa were completely removed (compared to the 1976 curriculum), and religions in Asia were limited to a choice between Hinduism and Buddhism. ${ }^{20}$ The special focus on Christianity and Islam was continued in the curriculum for 'Religion and Ethics' issued in 2006 (RE06), and fully implemented in the school year 2008/2009. The four main subject areas are now 1) Theory of religion and criticism of religion, 2) Islam and an elective religion (to be selected by the teacher and the pupils jointly), 3) Christianity, and 4) Philosophy, ethics and views on life/humanism (livssynshumanisme). ${ }^{21}$ The short introduction states that' $[t]$ he

19 In Norwegian: 'Læreplanen er skriven ut frå eit kristent, luthersk syn, og andre religionar og filosofiske retningar blir tolka ut frå ein kristen ståstad. Dette gjør at læreplanen verkar ekskluderande overfor elevar med anna religiøs bakgrunn eller overtyding' (Sámi instituhtta 2000, 135).

20 Much alike to the development in Denmark.

21 This is the official translation in English by the Directory of Education. Curriculum in English: http://data.udir.no/k106/REL1-01.pdf?lang=eng [last visited 1 July 2013]. 
subject emphasises religious and philosophical traditions in the Norwegian, European and international contexts' (RE06, 2). Based on this, it is difficult to identify why there is a special focus on Christianity and Islam.

Compared to the previous curriculum, the subject area 'theory of religion and criticism of religion', signals a more Study of Religions-based approach. The description reads:

The main subject area theory of religion and criticism of religion focuses on the extent ${ }^{22}$ of religions and views on life (livssyn) globally, nationally and locally. The main subject area introduces analytical tools as the basis for a holistic and balanced understanding of religions. This main subject area also focuses on fundamental issues arising from the role of religions in society (RE06, 2; official translation).

In the official translation by The Norwegian Directorate for Education and Training the specific goals for teaching reads (RE06, 4):

The aims of the studies are to enable pupils to

- elaborate on the geographical and demographical extent of religions

- present main characteristics of the diversity of religions and views on life (livssyn) in local communities and the greater society in Norway, including religion and views on life (livssyn) in Sami communities

- discuss different definitions of religion

- present, discuss and elaborate on different dimensions of religions: theory, myths

- $\quad$ and narratives, rituals, experiences, ethics, social organisation, art and material

- expressions

- discuss and elaborate on different forms of searching for religions in our time

- $\quad$ elaborate on and assess different types of criticism on religions and views on life (livssyn)

- discuss and elaborate on cooperation and tensions between religions and views on life (livssyn) and reflect on the pluralist society as an ethical and philosophical challenge

22 In the official translation the word 'extent' is used in English as translation of the Norwegian 'utbredelse'. The sentence in Norwegian reads: 'Hovedområdet religionskunnskap og religionskritikk handler om utbredelsen av religioner og livssyn både globalt, nasjonalt og lokalt'. 
The references to theoretical perspectives and definitions of religion again signal an approach inspired by the Study of Religions. However, as the teaching goals are made more specific, it is worth noting that there is only one teaching goal which deals explicitly with the criticism formulated in the heading, although it could also be argues that 'cooperation and tension between religions' might constitute kind of a critical perspective.

In the fourth teaching goal listed above, reference is made to 'dimensions of religions: theory, myths and narratives, rituals, experiences, ethics, social organisations, art and material expressions'. The inspiration is clearly from Ninian Smart and his well-known dimensional model for approaching and understanding religions (cf. Smart 1989). Smart's seven (and later eight) dimensions are not adopted with his exact terms, though. Theory, for instance, is not used by Smart, but the in the curriculum it corresponds to what Smart referred to as a doctrinal and philosophical dimension. In the main subject areas, where teaching goals are made explicit, one can see more clearly how Smart's model has been used. In the main subject area labelled 'Islam and an elective religion', it reads (RE06, 4):

The aims of the Studies are to enable pupils to

- elaborate on key features in the religion and discuss and elaborate on important

- characteristics of the religion's ethics

- interpret some of the religion's key texts

- elaborate on different disciplines[sic! $]^{23}$ in the religion

- describe and analyse some aesthetic and ritual expressions in the religion

- discuss and elaborate on the religion's view on gender and gender roles

- discuss and elaborate on the religion's view on other religions and views on life (livssyn)

- compare the religion to other religions and views on life (livssyn)

The dimension model seems to be meant to secure a similar or identical approach to all religions; yet Christianity, as a separate main subject area, is not approached only through these dimensions. There is one additional aim in the approach to Christianity stating that students should be enabled to 'elaborate on examples of continuity and change in the history of Christianity in and outside Europe' (RE06, 4).

23 The Norwegian text (gjøre rede for ulike retninger i religionen) actually ought to be translated 'different groups', or 'different traditions' rather than 'disciplines'. 
Compared to the curriculum for RE in primary and secondary schools, the 'cultural heritage' perspective on Christianity, however, is not as prevalent in 'Religion and Ethics'. The teaching goal quoted above on continuity and change in the history of Christianity is the closest to such a perspective.

All in all, the approach to religions has, as said, a Study of Religions profile, even though the use of the Smart model is a bit antiquated. Yet, although Smart's dimension model has been under criticism during the last decades (cf. Cox 2006, Wiebe 1999, Andreassen 2010), it could be argued that the dimension model, if combined with more critical perspectives on religion, may work adequately. It secures a comparative perspective, both as a theoretical concept and in the methodical approach to the different religions.

The fourth main subject area, philosophy, ethics and views on life/humanism (livssynshumanisme), is described as follows:

The main subject area philosophy, ethics and views on life/humanism (livssynshumanisme) focuses on selected philosophers from a number of epochs and from several regions of the world. The main subject area also looks into ethical concepts and argumentation models, and forms the basis for making one's own opinions and choices. This main subject area focuses on humanism in a historical and contemporary perspective. Continuity and tensions within the humanism tradition are key elements (RE06, 2; official translation).

This main subject area thus touches on a broad range of themes. A rather new area of content is the focus on philosophers from different regions of the world. In addition to two European philosophers, teaching should enable students to 'elaborate on the main ideas of one Chinese or Indian philosopher'. This might point in the direction of philosophers in Chinese or Indian religious traditions, and thus pave the way for a broader perspective than the one given in the other main subject areas and the clear focus on Christianity and Islam. However, this specific aim is considered a great challenge among RE teachers in upper secondary, since not many institutions in Norway offer courses in world philosophies. ${ }^{24}$

There is a slightly different focus in the learning objectives related to philosophy and views on life/humanism (livssynshumanisme), compared to the learning objectives concerning ethics. The former are more focused on knowledge, while, when it comes to ethics, students are supposed to be

24 The only course I know in 'World philosophies' focusing on Indian, Chinese and Middle Eastern philosophy is at the University of Bergen: https://miside.uib.no/fs-cron/download/103502626/RELV202_302_Verdensfilosofier_med_tema.pdf [Last visited 12 August 2013]. 
more engaged in dialogue, and the learning objectives concerning ethics are more oriented towards existential questions. This existential orientation is also highlighted in the introduction to the curriculum:

As a subject aiming to raise awareness and shape attitudes, religion and ethics shall also open for reflection on the pupil's own identity and own choices in life. The teaching in the subject shall stimulate each pupil to interpret life (livstolkning) and attitudes (RE06, 2; official translation).

To facilitate this, pupils should be able to 'conduct dialogues with others on relevant ethical questions', as one teaching aim reads.

In general, the main subject areas in the RE06 curriculum seem to be oriented towards or based upon a Study of Religions approach. Pupils should learn about theories of religion, and key terms and concepts in approaching and comparing religions. As regards ethics, though, a more existential approach, directed towards the student's personal growth and identity, can be noted. Trying to combine an existential and personal approach with a more academic approach to religion(s) seems be typical for Norwegian curricula since the 1990s. In textbooks one can detect an emphasis on ethics and the discussion of 'ethical cases' which are especially relevant for this specific age group. An observation - although not documented in classroom research or interviews with teachers - is that the Study of Religions orientation, which lies in the aforementioned main subject area, is not yet fully integrated in teaching and textbooks. Much teaching still revolves around ethical discussions embedded in Christian norms and values.

In comparison with RE in primary and secondary schools, the structure and content of RE in upper secondary are more or less the same. One may therefore question whether there is a progression from secondary to upper secondary. Following the curriculum might result in a teaching in upper secondary which more or less revolves around the same issues as in primary and secondary. However, in the curriculum for upper secondary education one might say that the focus is slightly more oriented towards topics of rituals, doctrine and confession. From the vantage point of Study of Religions, one might wish that the content of the main subject area 'theory of religion and criticism of religion' formed the main perspective throughout the whole curriculum. To signal a development from secondary to upper secondary education, one could thus think of a curriculum which focused more on religion as a human and social phenomenon and related religion to topics like media and politics. 


\section{Teacher Education}

There are several different ways of becoming a teacher in Norway. ${ }^{25}$ In general, the university colleges offer a four-year general teacher training, which qualifies for teaching in primary and secondary schools. Students specialise in teaching at either the first to seventh grades (primary school) or the fifth to tenth grades (secondary school). At (most of) the universities, however, students can also first complete studies in their academic subjects, and then take a one-year practical-didactical teacher training programme, which will qualify them for teaching two subjects in secondary and upper secondary schools.

Another teacher education model at the universities is a five-year integrated teacher training programme. During that period, students specialise in two subjects (with at least 60 ECTS credits each), ${ }^{26}$ alongside general pedagogy and subject-related didactics. The main difference from the oneyear practical didactical education is that pedagogy and subject-related didactics are integrated during the five years from the very beginning, while the one-year practical didactical education is an additional year consisting of pedagogy and subject-related didactics only, after five years of study (a total of six years). This also qualifies for teaching in secondary and upper secondary schools.

As illustrated in table 2, to specialise in teaching RE is an option in all teacher training models. RE is only one of several options for students to specialise in. In general teacher training, students specialise in four subjects for teaching at the 1st to 7 th grades, or three subjects for teaching at the 5 th to 10 th grades. For the one-year practical-didactical training

25 In general the university colleges (høyskoler) in Norway have been offering vocational education (profesjonsutdanning) on bachelor level (three or four years of study) such as general teacher education, pre-school teacher education, education for nurses (sykepleie) or physiotherapists. Universities, on the other hand, have been orientated towards the classical academic disciplines and, apart from (masters in) e.g. law and medicine, and a one-year practical-didactical teacher education for upper secondary school. The universities have not offered vocation-orientated education similar to that offered by the university colleges. However, this is changing, and recently some university colleges have been granted the status as a university, and others have merged with universities. This means that some of the new universities now offer educations earlier offered by the university colleges.

26 European Credit Transfer and Accumulation System (ECTS) is a standard for comparing the study attainment and performance of students in higher education across the European Union and other collaborating European countries. One academic year corresponds to 60 ECTS-credits that are equivalent to 1500-1800 hours of study (cf. http://www.studyineurope. eu/ects-system, [Last visited 8 October 2013]). 
Table 2: Teacher education models in Norway and the RE subject.

\begin{tabular}{|l|l|l|l|l|}
\hline $\begin{array}{l}\text { Type of teacher } \\
\text { education }\end{array}$ & Institution(s) & $\begin{array}{l}\text { Qualifies for } \\
\text { teaching in }\end{array}$ & $\begin{array}{l}\text { Subject studied } \\
\text { for specialising } \\
\text { in RE }\end{array}$ & $\begin{array}{l}\text { ECTS in RE or } \\
\text { in Study of Re- } \\
\text { ligions }\end{array}$ \\
\hline $\begin{array}{l}\text { Four-year } \\
\text { general teacher } \\
\text { education, } \\
\text { grades 1-7 }\end{array}$ & $\begin{array}{l}\text { University } \\
\text { colleges + some } \\
\text { universities }\end{array}$ & Primary school & $\begin{array}{l}\text { RLE (Religion, } \\
\text { views of life } \\
\text { (livssyn) and } \\
\text { ethics) }\end{array}$ & $30(+30)$ \\
\hline $\begin{array}{l}\text { Four-year } \\
\text { general teacher } \\
\text { education, } \\
\text { grades 5-10 }\end{array}$ & $\begin{array}{l}\text { University } \\
\text { colleges + some } \\
\text { universities }\end{array}$ & $\begin{array}{l}\text { Primary and } \\
\text { secondary } \\
\text { school }\end{array}$ & RLE & $30(+30)$ \\
\hline $\begin{array}{l}\text { One-year prac- } \\
\text { tical-didactical } \\
\text { training }\end{array}$ & $\begin{array}{l}\text { Universities + } \\
\text { some university } \\
\text { colleges }\end{array}$ & $\begin{array}{l}\text { Secondary and } \\
\text { upper second- } \\
\text { ary school }\end{array}$ & $\begin{array}{l}\text { Study of Reli- } \\
\text { gions } \\
\text { (or theology, } \\
\text { or philosophy) }\end{array}$ & $\begin{array}{l}60 \text { (or master's } \\
\text { degree) }\end{array}$ \\
\hline $\begin{array}{l}\text { Five-year inte- } \\
\text { grated teacher } \\
\text { training }\end{array}$ & Universities & $\begin{array}{l}\text { Secondary and } \\
\text { upper second- } \\
\text { ary school }\end{array}$ & $\begin{array}{l}\text { Study of Reli- } \\
\text { gions } \\
\text { (or theology, } \\
\text { or philosophy) }\end{array}$ & $\begin{array}{l}60 \text { (or master's } \\
\text { degree) }\end{array}$ \\
\hline
\end{tabular}

programme and the five-year integrated teacher training degree, students must specialise in a minimum of two subjects. ${ }^{27}$

For the four-year general teacher training there are comprehensive national guidelines. Here attainment targets concerning knowledge, skills and general competences are specified for the individual subjects. The names of the subjects in the general teacher training are the same as in primary and secondary school. In the national guidelines for general teacher training there is one description for RLE1 (the first 30 ECTS) and one for RLE2 (additional 30 ECTS). The course description for RLE in the national guidelines is clearly adapted to the RLE curriculum for primary and secondary education. It includes more or less the same: philosophy and ethics, secular world views (livssyn), and the typical world religion approach (Judaism, Christianity, Islam, Hinduism and Buddhism), with a special emphasis on Christianity.

27 In the curriculum of 2003 there is an opening for universities to accept students that only have one teaching subject. This mean that a student could have a bachelor's degree consisting of two or three academic disciplines (such as history of arts, study of religions and courses in classical Greek language and culture), but only one of them (study of religions) qualifies for teaching in school. However, most of the universities demand two subjects relevant for teaching in school. The requirement of two subjects is suggested to be obligatory in the new curriculum for the one-year practical didactical teacher education from 2014 onwards. 
However, the 'cultural heritage' perspective is somewhat played down in the teacher training guidelines. The general description for RLE states that 'Christian faith and tradition in particular have influenced Norwegian culture and history' ${ }^{28}$ It does not say anything about whether or how this should influence the teaching or perspective in RLE. In the more specific attainment targets, it states that students should gain knowledge about 'religions and philosophies of life (livssyn) in the subject [RLE in primary and secondary]: diversity and different traditions, faith and belief, practice, ethics and esthetical expressions, with a special emphasis on Christianity and Norwegian conditions' (my translation). ${ }^{29}$ Thus, there is a special emphasis on Christianity, but not in the same way as in primary and secondary school, where the 'cultural heritage' perspective signals a more qualitatively different treatment of Christianity. It rather describes Christianity as the religious tradition which has been present in Norway for a long period. This again is regarded as a reason to use most time for teaching about Christianity.

It is also worth noticing a special focus on human rights. It states that students should have 'knowledge about human rights and the UN Convention on the Rights of the Child and the debates concerning the consequences thereof for teaching RLE' ${ }^{30}$ The entire human rights debate, with the criticism from the UN and ECHR, is thus integrated into the training of $\mathrm{RE}$ teachers. This is supplemented with a special aim stating that students should be able to 'combine the requirement of an objective, critical and pluralistic teaching in RLE with varied, pupil-active and engaging ways of teaching ${ }^{\prime}{ }^{31}$ The international criticism and the subsequent national debate have thus left a definite mark on teacher training, and the guidelines reveal the efforts to strike a balance, between a special emphasis on Christianity and the qualitatively equal treatment of all religions.

From a Study of Religions perspective, the new national guidelines for general teacher training most definitively constitute an improvement. However, traces from a previous more theological and empathetic tradition, according to which the role of the RE teacher was to be a 'good person'

28 'Kristen tru og tradisjon har i særlig grad prega norsk kultur og historie' (National guidelines, RLE 5-10, 70).

29 'Studenten har kunnskap om religionar og livssyn i faget: mangfald og ulike retningar, trusinnhald og oppfattingar, praksis, etikk og estetiske uttrykk, med særleg vekt på kristendommen og norske forhold' (National guidelines, RLE 5-10, 71).

30 'Studenten har kunnskap om menneskerettane og FNs barnekonvensjon og diskusjonane om ulike konsekvensar av desse for undervisninga i RLE' (National guidelines 5-10, 71).

31 'Studenten kan kombinere kravet om objektiv, kritisk og pluralistisk undervisning i RLE med varierte, elevaktive og engasjerande arbeidsmåtar' (National guidelines 5-10, 72). 
and a role model for everybody in the school system, can still be detected. In the current guidelines, this tradition can be detected in the supposed special role of the RE teacher as someone who has an obligation to create a good relationship between the school and the pupil's home (parents), and to 'build bridges' between 'common values' (as expressed in the Education Act) and human rights. The special role that current guidelines allocate to the RE teacher is thus still that of a 'caretaker' of common values and as a 'good person'.

The teacher training programs that students can take at the universities do not have the same kind of national guidelines as general teacher training. The regulations (forskrift) for these study programs only state that the academic discipline and the courses offered must be relevant for teaching in school and that students should have 15 ECTS didactics related to each of the two subjects they study. To get an insight into what is considered relevant, one has to look at the locally developed descriptions and course plans of the individual institutions. Due to limited space, I will not give examples of such locally developed descriptions and course plans.

For the one-year practical-didactical teacher training the issue of finding relevant course content is a rather challenging one. The fact that both theology and philosophy are in principle considered equally relevant as Study of Religions (see table 2) for teaching RE in school has to do with university politics. It partly illustrates why RE in teacher training has commonly been considered as 'the theologians' subject', as it used to be religious institutions which mainly educated teachers for teacher training, especially the university colleges (cf. Skeie 2003, Andreassen 2009). The religious institutions have had a strong interest in promoting their relevance for RE in school and for teacher training in general, pointing to the emphasis on Christianity in the curricula as part of their argumentation. The 1998 curriculum for the one-year practical-didactical training program, after the implementation of the KRL subject in primary and secondary, stated however that several academic disciplines were relevant for teaching this subject:

Although the school subjects incorporate topics from several university subjects [academic disciplines], it is first and foremost the academic disciplines of Knowledge of Christianity / theology, Study of Religions, and philosophy, which are the basis for training in the subject and the program for practicaldidactical teacher training. (KUF 1998, 109; my translation.) 
This allowed institutions to accept students who had studied philosophy or theology, as well as students with a bachelor's degree in Study of Religions, to apply for the one-year practical-didactical training at the university. In practice, this meant that students with only theology or philosophy could be allowed to teach RE at all levels after the one-year course, even if this meant that this would produce teachers that had an academic background which only covered about 20 to 50 per cent of the school subject. This is obviously a great challenge, and a paradox, in teacher training. The new regulations and the new curriculum of 2003 gave more room to the institutions to decide whether or not students with only theology or philosophy should be accepted. Currently, some universities do not accept students with only theology or philosophy to specialise in teaching RE, but some still do.

Also in the national guidelines for RE in general teacher training, theology and philosophy are featured as relevant academic disciplines for teaching RE in primary and secondary, in addition to Study of Religions. However, in general teacher training, the subject for specialising in RE is RLE - with more or less the same content as in primary and secondary. There is, of course, also still a rather big difference between RLE at the university colleges and Study of Religions at the universities. The latter provides students with familiarity with Study of Religions as an academic discipline, especially in terms of theoretical and comparative perspectives. Although comparison and insider and outsider perspectives are now integrated into RLE at the university colleges, theoretical perspectives are more or less absent, and the focus is to a much broader extent on basic introductions to different religions, philosophy and ethics. The teaching at the university colleges is also influenced by the background of the university college teachers: Traditionally, teachers in the general teacher training were recruited from theological seminars or religious university colleges. Again, one can see why KRL/RLE in general teacher training has been regarded as the 'theologians' subject' (cf. Skeie 2003, 192-3). The Study of Religions departments have only to a limited extent been able to produce scholars to teach at these institutions. Hopefully this will change in the years to come.

\section{Concluding Remarks}

Seen from the vantage point of Study of Religions, the recent developments have been largely positive, most visibly through the change in name from KRL to RLE, but more importantly in the way the curriculum focuses on objective, critical and pluralistic teaching and the fact that the pupils should 
learn about (not from) religions. These have been important measures in the process towards securing that religions will be dealt with in a qualitatively equal way, in the aftermath of the criticism from the UN and ECHR. These are principles which have mainly brought the RLE subject closer to the academic study of religion.

However, the current Education Act $(\S 2-4)$ still states that ' $[t]$ eaching in RLE shall transmit knowledge of Christianity, other world religions and philosophies of life (livssyn), knowledge of what Christianity has to say as cultural heritage and to ethical and philosophical topics'. It thus represents an on-going deliberate political intention to promote Christianity as the 'cultural heritage' of Norway. This means that there is still a tension between a 'cultural heritage' perspective and the Norwegian state's commitment to human rights, especially in primary and secondary education. Both this political agenda, and the prevailing thinking about religions in RE in primary and secondary, are thus still somewhat remote from the basic principles in Study of Religions. Moreover, if the name of the RLE subject is now changed to KRLE, this would shift the subject further away from Study of Religions, and it would mean a real setback after several years of positive developments.

In teacher training, I think, future RE teachers ought explicitly to be made aware of this qualitative bias towards Christianity in the Education Act, and how this might influence the actual teaching of RE in school. While the extended tradition of Christianity in Norway for a long time made RE in school and teacher training the theologians' subject, the development in the last decade has brought RE, both in school and in teacher training, closer to Study of Religions. There is, however, as I see it, still room for improvement,- and thus for scholars in Study of Religions to also be actively engaged in RE at all levels in the years to come. 


\section{Bibliography}

Aadnanes, Per M. \& Kai I. Johannessen (eds)

2000 Et Fag for enhver smak?: en evaluering av KRL-faget. Høgskulen $i$ Volda. Oslo: Norges forskningsråd, (Diakonhjemmets høgskolesenter).

\section{Alberts, Wanda}

2007 Integrative Religious Education in Europe. A Study-of-Religions Approach. Berlin: De Gruyter.

2011 Religious education in Norway. - Leni Franken \& Patrick Loobuyck (eds), Religious Education in a Plural, Secularised Society. A Paradigm Shift, 99-114. Münster: Waxmann.

\section{Andreassen, Bengt-Ove}

2009 Seige strukturer. Perspektiver på endring og diskursivt arbeid i norsk religionsdidaktikk. - Din. Tidsskrift for religion og kultur 1, 5-29.

2010 Bruk eller misbruk? Ninian Smarts dimensjonsmodell i tilnærmingen til religion i norsk religionsdidaktikk. - Religionsvidenskabeligt tidsskrift $55,55-73$.

\section{Bondevik, Kjell Magne}

2006 [2004] [Untitled. Speech given at the opening of a conference in Oslo 6 June 2004]. -The Religious Dimension of Intercultural Education. Conference proceedings Oslo, Norway, 6 to 8 June 2004, 21-22. Strasbourg: Council of Europe Publishing.

Circular F-10-08 [The Ministry of Education]

2008 Informasjon om endringer i opplæringsloven. Oslo: Kunnskapsdepartementet.

Core curriculum [The Royal Ministry of Education, Research and Church affairs]

1993 Core Curriculum. Oslo: The Royal Ministry of Education, Research and Church affairs.

Cox, James L.

2006 A Guide to the Phenomenology of Religion. London: T\&T Clark International.

ECHR [European Court of Human Rights]

2007 Case of Folgerø and Others vs. Norway (Application no. 154/02).

Hagesæther, Gunhild \& Signe Sandsmark \& Dag-Askild Bleka

2000 Foreldres, elevers og læreres erfaringer med KRL-faget. Bergen: NLA-forlaget (Norges forskningsråd).

Høstmælingen, Njål

2004 The Teaching of Religion in Primary and Secondary Schools in Nor- 
way.- Peter Lødrup \& Eva Modvar (eds), Family Life and Human Rights, 291-304 Oslo: Gyldendal akademisk.

\section{Haakedal, Elisabet}

2001 From Lutheran Catechism to World Religions and Humanism: Dilemmas and Middle Ways through the Story of Norwegian Religious Education. - British Journal of Religious Education 23 (2), 88-97.

Innst. S. nr. 103 (1995-1996) [White paper, report to parliament]

1995 Innstilling fra kirke-, utdannings- og forskningskomiteen om kristendomskunnskap med religions- og livssynsorientering. Oslo: The Royal Ministry of Education, Research and Church affairs.

Innst. O. nr. 95 (1996-1997) [White paper, report to parliament]

1996 Innstilling frå kyrkje-, utdannings- og forskingskomiteen om lov om endringar i lov av 13. juni 1969 nr. 24 om grunnskolen m.m. Oslo: The Royal Ministry of Education, Research and Church affairs.

Jensen, Tim

2008 RS based RE in public schools: a must for a secular state. - Numen 55 (2-3), 123-50.

2011 Why Religion Education, as a Matter of Course, ought to be a Part of the Public School Curriculum. - Leni Franken \& Patrick Loobuyck (eds), Religious Education in a Plural, Secularised Society. A Paradigm Shift, 131-49. Münster: Waxmann.

\section{Kirke-, utdannings- og forskningsdepartementet [KUF]}

1998 Rammeplan og forskrift for praktisk-pedagogisk utdanning. Fastsatt 01.07.99 av Kirke-, utdannings- og forskningsdepartementet. Oslo: The Royal Ministry of Education, Research and Church affairs.

\section{L97}

1996 Læreplanverket for den 10-årige grunnskolen. Oslo: The Royal Ministry of Education, Research and Church affairs.

\section{Leirvik, Oddbjørn}

2001 Religionsdialog på norsk. Oslo: Pax forlag.

\section{Lied, Sidsel}

2009 The Norwegian Christianity, Religion and Philosophy subject KRL in Strasbourg. - British Journal of Religious Education 31(3), 263-75.

\section{Møse, Erik}

1998 [1997] Fritak for undervisning i faget kristendomskunnskap med religions- og livssynsorientering. Forholdet til Norges folkerettslige forpliktelser. - Njål Høstmælingen (ed.), Livssyns- og trosfrihet $i$ et menneskerettighetsperspektiv. Særlig om faget kristendomskunnskap med religions- og livssynsorientering, 123-211. Oslo: Juristforbundets forlag. 
National Guidelines 5.-10. [The Ministry of Education and Research] 2010 Religion, livssyn og etikk. - Nasjonale retningslinjer for grunnskolelærerutdanningen 5. - 10. trinn, 70-4. Oslo: Kunnskapsdepartementet.

NOU 1995:9 [Norwegian official report]

1995 Identitet og dialog. Kristendomskunnskap, livssynskunnskap og religionsundervisning. Oslo: Kirke-, utdannings- og forskningsdepartementet (NOU1995:9 Identitet og dialog).

\section{Østnor, Arna}

1997 Ny læreplan i Religion og etikk: prosess og produkt... - Religion og livssyn 1, 4-13.

\section{Plesner, Ingvill T.}

2013 Religion and education in Norway. - Derek H. Davis \& Elena Miroshnikova (eds), The Routledge International Handbook of Religious Education, 243-50. London - New York: Routledge.

\section{Rasmussen, Tarald}

2000 The New Norwegian "KRL" Subject and Religious Freedom: a Report. - Studia Theologica 54, 19-34.

\section{RE96}

1996 Læreplan for videregående opplæring. Religion og etikk. Felles allment fag.

Oslo: The Royal Ministry of Education, Research and Church affairs.

\section{RE06}

2006 Religion and ethics - common core subjects in Programme for general studies.

Oslo: Directorate for Education and Training.

\section{RLE08}

2008 Curriculum for Religion, Philosophies of Life and Ethics. Oslo: Directorate for Education and Training.

\section{Sámi instituhtta}

2000 Samisk videregående opplæring. Rettigheter og innhold. Evaluering av samisk videregående opplæring under Reform94. Kautokeino: Nordisk Samisk Institutt.

\section{Skeie, Geir}

2003 KRL - et fag på frammarsj? - Gustav E. Karlsen \& Inger Kvalbein (eds), Norsk lærerutdanning. Søkelys på allmennlærerutdanningen $i$ et reformperspektiv, 189-206. Oslo: Universitetsforlaget.

2006 Diversity and the political function of religious education. - British Journal of Religious Education 28 (1), 19-32.

\section{Skottene, Ragnar}

1997 Religionsfagets ideologiske profil i den videregående skolen. - Norsk pedagogisk tidsskrift 3, 141-9. 


\section{Smart, Ninian}

1989 The World's Religions. Cambridge: Cambridge University Press.

St. meld. nr. 20 2012-2013 [White paper, report to parliament]

2013 På rett vei. Kvalitet og mangfold i fellesskolen. Oslo: Ministry of Education.

\section{Thomassen, Einar}

2006 Religious Education in a Pluralistic Society: Experiences from Norway. - Michael Pye \& Edith Franke \& Alef Theria Wasim \& Ma'sud Abdurrahman (eds), Religious Harmony, 257-66. Berlin: de Gruyter.

Udir. [Utdanningsdirektoratet]

2005 KRL-boka. Oslo: Directorate for Education and Training.

United Nations. Human Rights Committee

2004 Leirvåg et al v Norway, Communication No. 1155/2003, adopted 3 November 2004 (CCPR/C/82/D/1155/2003).

Wiebe, Donald

1999 The Politics of Religious Studies. New York: Palgrave.

\section{Wingård, Guri Jørstad}

2003 Er Troen virkelig en Skole-Sag? - Rune Slagstad \& Ove Korsgaard \& Lars Løvlie (eds), Dannelsens forvandlinger, 334-46. Oslo: Pax forlag. 